\title{
Lyric and Landscape in Rimsky-Korsakov's Songs
}

\section{Philip Ross Bullock}

Accounts of Russian musical realism in the nineteenth century have tended to emphasize music's connections to literature, whether in the form of operatic adaptations of plays and prose works, or of songs, such as those of Modest Musorgsky, described by the composer as "the reproduction in musical sounds not merely of the mood of feelings, but mainly of the mood of human speech." ${ }^{1}$ Yet literature was not the only source of music's realist aspirations. Realism in France, for instance, was initially associated with the visual arts and only afterward taken up in literature. ${ }^{2}$ A persistent critical emphasis on the supposed primacy of the word within Russian culture has occluded awareness of similar developments in the other Russian arts, where the kind of realisms that were characteristic of visual culture on the one hand, and literature on the other, have generally been

This article is based on a paper delivered at the "Hearing Landscape Critically" conference, Harvard, January 2015; my thanks are due to audience members at this conference for questions and comments, and to the Music \& Letters Trust for facilitating my attendance. Earlier iterations of some of the ideas developed here were first heard at seminars held at Leeds, Oxford, Stanford, and University College London. The article was finally written during a period of research leave supported by the award of a British Academy Mid-Career Fellowship and a EURIAS fellowship at the Paris Institute for Advanced Study (France), co-funded by Marie Skłodowska-Curie Actions, under the European Union's Seventh Framework Programme for research, and from funding from the French State managed by the Agence Nationale de la Recherche, programme "Investissements d'avenir" (ANR-11-LABX-0027-01 Labex RFIEA+).

${ }^{1}$ Modest Petrovich Musorgsky, “Avtobiograficheskaya zapiska,” in Literaturnoye naslediye, ed. A. A. Orlova and M. S. Pekelis, 2 vols. (Moscow: Muzïka, 1971-2), I, 267-70, here 270. See also Richard Taruskin, "Handel, Shakespeare, and Musorgsky: The Sources and Limits of Russian Musical Realism,” in Musorgsky: Eight Essays and an Epilogue (Princeton: Princeton University Press, 1993), 71-95, as well as his "Realism and Preached and Practiced: The Russian Opéra Dialogué," Musical Quarterly 56/3 (1970): 431-54.

${ }^{2}$ Peter Brooks, Realist Vision (New Haven and London: Yale University Press, 2005). 
treated as parallel trends, rather than as a nexus of profoundly intertwined aesthetic and ideological phenomena. $^{3}$

When considering realism in Russian music, it may therefore be as productive to look for analogies with the visual arts as it is to continue to employ familiar comparisons with literature. ${ }^{4}$ This is especially the case when it comes to the works of Nikolay Rimsky-Korsakov, as one of his earliest English critics, Rosa Newmarch, observed:

In speaking of Korsakov's work, it seems natural to drop into the language of the studio. To me, he always appears as a descriptive poet, or still more as a landscape painter, who has elected music for his medium. Gifted with a brilliant imagination, yet seeing with a realist's vision, he is far more attracted to what is capable of definite expression than towards abstract thought. $^{5}$

When a temperament, musically endowed, sees its subject with the direct and observant vision of the painter, instead of dreaming it through a mist of subjective exaltation, we get a type of mind that naturally tends to a programme, more or less clearly defined. Rimsky-Korsakov belongs to this class. Labelled or not, we feel in all his music the desire to depict. ${ }^{6}$

\footnotetext{
${ }^{3}$ For a recent account of Russian realism that emphasizes precisely the interaction of literature and visual culture, see Molly Brunson, Russian Realisms: Literature and Painting, 1840-1890 (Dekalb: Northern Illinois University Press, 2016).

${ }^{4}$ For a survey of the relationship between music and visual culture in nineteenth-century Russia, see Leon Botstein, "Music as the Language of Psychological Realism: Tchaikovsky and Russian Art," in Tchaikovsky and His World, ed. Leslie Kearney (Princeton: Princeton University Press, 1998), 99-144.

${ }^{5}$ Rosa Newmarch, “The Development of National Opera in Russia: Rimsky-Korsakov,” Proceedings of the Musical Association 31 (1904-5): 115.

${ }^{6}$ Rosa Newmarch, The Russian Opera (London: Herbert Jenkins, 1914), 333.
} 
Newmarch's gesture is, in part, a product of her debt to Vladimir Stasov, a pugnacious advocate of critical realism and the principal ideologue of both the moguchaya kuchka ("Mighty Handful") in music, and the peredvizhniki ("Itinerants") in the visual arts. Yet there is evidence enough in the composer's own memoirs to justify Newmarch's emphasis on his susceptibility to natural phenomena and the related "painterliness" of his musical aesthetics.

Take, for instance, this description of the Niagara Falls, which he saw during an extensive world tour that he undertook between 1862 and 1865, when still an officer in the Russian navy:

The banks of the Hudson proved to be very beautiful, and the Niagara Falls made the most marvelous impression on us. This was in November, I think. The leaves on the trees were of many colors; the weather was marvelous. We climbed all over the rocks, went as far as we could under the arch of the waterfall on the Canadian side, and rowed as close as possible to the waterfall. The impression made by the waterfall from various points, especially from the Terrapin Tower, is incomparable. ${ }^{7}$

Or his account of crossing the Tropic of Cancer:

The wonderful weather, the even warm wind, the gently lapping sea, and the dark-azure sky with white cumulous clouds did not change during the course of our passage through the blessed zone of the trade winds. Wonderful days and wonderful nights! The marvelous darkazure color of the sky by day would give way to a fantastic phosphorescent glow by night. As we headed farther south the twilight grew ever shorter, whilst the southern sky with its new constellations became ever clearer. Such radiance of the Milky Way, with the constellation of

\footnotetext{
${ }^{7}$ N. Rimsky-Korsakov, “Letopis' moyey muzikal'noy zhizni,” in Polnoye sobraniye sochineniy: literaturnïye proizvedeniya i perepiska, 8 vols. in 10 (Moscow: Gosudarstvennoye muzikal'noye izdatel'stvo, 1955-82), I (1955),

29.
} 
the Southern Cross, what a marvelous star Canopus (in the constellation of Argo), the stars of the Centaur, the brightly blazing red Antares (in Scorpio), visible in Russia as a pale star on bright summer nights! Sirius, familiar in Russia from winter nights, seemed here twice as large and twice as bright. Soon all the stars of both hemispheres became visible. The Big Dipper hung low above the horizon, whilst the Southern Cross rose ever higher. The light of the full moon passing between the cumulous clouds was simply dazzling. Wonderful is the tropical ocean with its azure color and phosphorescent light, wonderful are the tropical sun and clouds; but the tropical sky over the ocean by night is the most wonderful thing of all in the world. ${ }^{8}$

Later, during family holidays in rented dachas, Rimsky-Korsakov would trace the impact of the Russian countryside to the atmosphere of certain compositions. He described the summer of 1880 , which he spent in the village of Stelyovo, in rhapsodic terms:

Here everything was to my liking, everything delighted me. The beautiful location, the charming groves..., a vast forest by the name of Volchinets, the fields of rye, buckwheat, oats, flax, and even wheat, a multitude of scattered villages, the little river where we bathed, the proximity of a large lake, Vrevo, the impenetrable roads, the solitude, the ancient Russian names of the villages... - everything threw me into a state of rapture. The excellent garden with a multitude of cherry and apple trees, currants, strawberries, gooseberries, lilacs in bloom, a multitude of wild flowers, and the ceaseless singing of the birds - everything was somehow in a particularly harmonic relationship with my pantheistic mood at the time and my affection for the plot of Snegurochka (The Snow Maiden). ${ }^{9}$

\footnotetext{
${ }^{8}$ Ibid., 31.

${ }^{9}$ Ibid., 133.
} 
And at Vechasha, where he spent the summers of 1894 and 1895, he not only worked on Noch' pered Rozhdestvom (Christmas Eve), but began to contemplate his next opera too:

I recall that the place where I composed such material was often on the long boards running from the shore to the bathing-house on the lake. The boards ran among reeds; on one side one could see the tall willows bending in the garden, and on the other side lay the wide expanse of Lake Pesno. All of this somehow predisposed me to thoughts of Sadko. ${ }^{10}$

The memoirs of Rimsky-Korsakov's friend and amanuensis, Vasily Yastrebtsev, reinforce the notion that the composer perceived a direct link between his perception of the natural world and his creative work. Yastrebtsev, for instance, records Rimsky-Korsakov's claim that "all tonalities, modes, and chords, at least for me personally, are to be found exclusively in nature itself, in the color of the clouds, or even in the strikingly beautiful shimmering of the columns of light of the Northern Lights, and in the play of its luminous rays. That's where the real C sharp is, and B, A flat, and anything else you want." ${ }^{11}$ Elsewhere, Yastrebtsev records the strikingly precise details of Rimsky-Korsakov's synaesthesia: “C major seems white: E-flat major - darkish and gloomy; G major - radiant, joyful, and open; A-flat major...has a violet, or rather grayish-violent tinge; A minor strikes him as being partly rose-colored...like the glow of sunset on a cold, white, snowy landscape in winter, whereas A major is dawn itself, whether in spring or summer, bright, fiery, full of life, youth, and beauty." 12

By taking into account Rimsky-Korsakov's predisposition to the visual, it becomes possible to root his aesthetics in the intellectual context of the mid-century, when realism, positivism, and utilitarianism served as markers of an individual's progressive ideological outlook. As the

\footnotetext{
${ }^{10}$ Ibid., 196.

${ }^{11}$ Vasily Vasil'yevich Yastrebtsev, Nikolay Andreyevich Rimsky-Korsakov: vospominaniya, 2 vols. (Leningrad: Gosudarstvennoye muzïkal'noye izdatel'stvo, 1959-60), I, 176.

12 Ibid., I, 122.
} 
composer himself recalled of the time he spent sailing the world: "There was quite a good library on the clipper, and we read rather a lot. Sometimes lively discussions and arguments would ensue. We were influenced by the trends of the ' 60 s too. There were progressives and conservatives in our midst....We read Buckle, who was in great vogue in the '60s, Macaulay, [John] Stuart Mill, Belinsky, Dobrolyubov, and so on. We read fiction as well."13 A name not included here, but certainly implied by association, is that of Nikolay Chernïshevsky, the radical philosopher and novelist whose treatise, Esteticheskiye otnosheniya iskusstva k deystvitel'nosti (The Aesthetic Relations of Art to Reality, 1855) proposed that "the first object of art is the reproduction of reality." ${ }^{14}$ Rimsky-Korsakov's indebtedness to the principles of realist aesthetics can be seen in his reaction to a painting by his friend, Mikhail Vrubel' (whose wife, Nadezhda Zabela, premiered the soprano roles in a number of his later operas):

On one of my visits to M. A. Vrubel', he showed me his painting Morskaya tsarevna (The Sea Princess). The painting depicts, amongst other things, dawn and the moon in the form of a sickle, the latter with its concave face towards the dawn.... I drew the artist's attention to this mistake by explaining that at dawn only the waning moon can be seen, but never the new moon, and that, furthermore, it is the convex side that always faces the sun. M. A. was convinced of his mistake, but refused to redo his painting. I do not know whether the painting retains this astronomic incongruity, or whether as a result he changed it after all. ${ }^{15}$

As well as revealing much about Rimsky-Korsakov's down-to-earth, pragmatic personality, this statement suggests how his nautical background triumphed over aesthetic sympathy with the

\footnotetext{
${ }^{13}$ Rimsky-Korsakov, “Letopis’ moyey muzïkal'noy zhizni,” 26.

${ }^{14}$ N. G. Chernïshevsky, “Esteticheskiye otnosheniya iskusstva k deystvitel'nosti,” in Polnoye sobraniye sochineniy, 16 vols. (Moscow: Gosudarstvennoye izdatel'sto khudozhestvennoi literature, 1939-53), II (1949), 78.

${ }^{15}$ Rimsky-Korsakov, “Letopis’ moyey muzïkal'noy zhizni,” 212.
} 
imaginative capabilities of a fellow artist. His sensitivity is to nature itself, and not to artistic representations of nature that contradict its basic physical laws.

Opera and programmatic orchestral works are the most obvious places to look for music's engagement with the visual, whether through evocations of the natural world, or through a dialogue with pre-existing representations in visual culture. ${ }^{16}$ Yet the painterly qualities of RimskyKorsakov's music extend to other, perhaps more unexpected genres, and the visual is a defining feature of his work in the field of song too. Here, the visual is expressed through a persistent interest in landscape. Of Rimsky-Korsakov's 79 solo songs and five duets, a substantial number set lyrics that either deal explicitly with nature, or treat the natural environment as a backdrop for the expression of human emotion. César Cui claimed that "Rimsky-Korsakov's best songs - his descriptive ones - are landscapes in sound," ${ }^{17}$ and in an earlier review, he singled out a typical example of this genre:

\footnotetext{
${ }^{16}$ A related question is that of Rimsky-Korsakov's attitude to the scenic elements involved in productions of his operas.
} Although he was undoubtedly grateful to Savva Mamontov for sponsoring important productions of his operas at his Private Opera in Moscow, he showed little affinity with symbolist notions of the union of the arts, reacting tetchily to elaborate costuming, set designs, and interruptions to the dramatic flow of the work to facilitate scene changes. As Olga Haldey observes: "Throughout his career, Rimsky-Korsakov had always been firmly convinced that music, indeed singing, was opera's structural dominant, while other aspects of its production were relatively unimportant. Selfprofessed 'sight-deaf,' he was reluctant to discuss 'painterly and visual matters' related to his operas - even Vrubel's designs, despite his close friendship with the artist and his wife, Nadezhda Zabela. He was not, and would not be, included in the collaborative process of Mamontov's enterprise beyond occasionally conducting the orchestra." See Mamontov's Private Opera: The Search for Modernism in Russian Theater (Bloomington: Indiana University Press, 2010), 101.

${ }^{17}$ Ts. A. Kyui, Russkiy romans: ocherk ego razvitiya (St Petersburg; N. F. Findeizen, 1896), 143. Compare E. M. Petrovsky’s description of Rimsky-Korsakov’s 1898 setting of Apollon Maykov’s "Nimfa" ("Nymph”): “individuals who are disposed to perceive colors in sound would undoubtedly find that from start to finish this charming, soulful piece shimmers with a tender and alluring shade of blue, and a limpid and captivating coolness." Cited in Yastrebtsev, Nikolay Andreyevich Rimsky-Korsakov: vospominaniya, II, 87. 
"Noch"” ("Night"), with words by Pleshcheyev, is a charming, perfumed little picture, full of unusual freshness and beauty, one of the most captivating musical landscapes that have the great advantage over painted ones that a consecutive series of moments can be depicted in them, whereas painting is capable of portraying just one of them. Korsakov's talent for this kind of music is well-known, and "Noch"" belongs to the happiest of his inspirations. Under the bewitching influence of Korsakov's music, and without being a poet, you feel yourself in a deep forest, you breathe in the bracing smell of fir resin, you hear the flowing of a brook, the sounds of a nightingale are carried to you through the silence of night, above you is the starry sky and the expanse of the air... The music of "Noch" is shot through with Russian national identity (narodnost'). ${ }^{18}$

Cui's comments allow us to tease out some of the potential ramifications for thinking of RimskyKorsakov's songs in terms of their relationship to landscape. Firstly, the work's "unusual freshness and beauty" situates it within the discourse of artistic verisimilitude, inasmuch as it is held to capture qualities that are characteristic of the represented object itself. Second, and relatedly, music achieves more than mere literary representation (Cui barely even mentions Pleshcheyev's original poem), just as it seems to bypass visual mediation to evoke the object of representation itself (here the night). Third, Cui recognizes that music's somatic power (its "bewitching influence") gives rise to a corresponding imaginative response on the part of its listeners, partly through quasi-realistic mimesis ("the bracing smell of fir resin," "the flowing of a brook, the sounds of a nightingale"), but also through association and embodied presence. Finally, his comments about the song's national identity reveal how landscape is never an innocent category of objective representation, but functions instead as a means of creating communities of listeners through the projection of familiar

18 “Muzïkal'nïye zametki," Sanktpeterburgskiye vedomosti, 12 November 1870, reprinted as “Sbornik malorossiyskikh pesen Rubsta. Vnov’ izbrannïye sochineniya Balakireva, Korsakova, Borodina, Musorgskogo,” in Ts. A. Kyui, Izbrannïye stat'i, ed. I. L. Gusin (Leningrad: Gosudarstvennoye muzïkal'noye izdatel'stvo, 1952), 167-75, here 172. Cui's account of the song is repeated, in modified form, in Russkiy romans, 144-45. 
tropes. There is, in fact, little about Pleshcheyev's "Night" that refers directly to Russia itself; it is, rather, Rimsky-Korsakov's song that stages the work's national identity through the use of musical gestures that could be read as somehow "typically" Russian by contemporary audiences.

Realism was not simply an aesthetic category that was central to the Russian arts in the middle of the nineteenth century; it also functioned as a means of ideological judgment in the Soviet period. S. D. Maggid's 1930 account of the stylistic features of Rimsky-Korsakov's songs divides them into two main periods:

1866-82: 32 songs (opp. 2, 3, 4, 8, 25, 26, and 27)

1897-98: 47 songs (opp. 39, 40, 41, 42, 43, 45, 46, 49, 50, 51, 55, and 56)

In both cases, landscape defines both Rimsky-Korsakov's choice of texts and his handling of musical form. In the first period, as Maggid observes, "it is the oriental songs, with their highly characteristic and replete coloration that stand out most clearly." The second period, however, marks a new departure for the composer: "It is at this point that Rimsky-Korsakov finds his own style. Lyrical landscape songs and lyrical contemplative songs come one after the other."19 Vera Vasina-Grossman shares Maggid's emphasis on landscape, and more broadly on the visual as a crucial facet of Rimsky-Korsakov's musical language, arguing that his output "reflects various stages in the development of realism in Russian music."20 Suggesting that "Rimsky-Korsakov was a creative artist who could see the world clearly and crisply, no less than painters could," she describes his songs as "pictures of nature, peaceful and calm, filled with internal harmony and radiance."21

\footnotetext{
${ }^{19}$ S. D. Maggid, "Stilicheskiye osobennosti romansov N. A. Rimskogo-Korsakova," in Russkiy romans: opït intonatsionnogo analiza, ed. B. V. Asaf'ev (Moscow and Leningrad: Academic, 1930), 148.

${ }^{20}$ Vera Vasina-Grossman, Russkiy klassicheskiy romans XIX veka (Moscow: Izdatel'stvo Akademii nauk SSSR, 1956), 228.

${ }^{21}$ Ibid., 230.
} 
Yet a note of caution is in order here. To emphasize unreflectively the visual correlatives of Rimsky-Korsakov's musical imagination may simply result in a reductive re-inscription of representation as the dominant, even exclusive, mode of mid-nineteenth-century Russian aesthetics. ${ }^{22}$ A more productive approach to Rimsky-Korsakov's handling of the visual may be to link questions of representation to those of space and subjectivity. As Jim Samson argues, landscape is a particularly productive expression of the visual, inasmuch as it functions both as a particular spatial environment, and as a marker of how that environment is experienced:

It is after all widely recognized that a sense of place - of "being there" - is a prerequisite of subjectivity, or at least so deeply rooted in subjectivity that it is crucial for our identity formation....For the more experiential aspect of this process some cultural geographers have used the term landscape, which might be understood as a subset of place, rather as place is a subset of space. Thus a landscape is defined by our entire experience of a place, and that includes conceptualizing it and dwelling it, in a Heideggerian sense.... A landscape thus becomes a kind of cultural image, and since it operates partly in an imaginative realm it is open to contestation. Music may be constitutive of such a cultural image, and through its associative power it can help weld the landscape to history, to collective social and even national identities. ${ }^{23}$

In Russian, this question becomes yet more productive and multifaceted, as there are at least two words that can be used to render the single English term "landscape." As Christopher Ely notes, the first - landshaft - "usually refers to a visible section of terrain." By contrast, the second - peizazh -

\footnotetext{
${ }^{22}$ For a more productive approach to the topic, see Joshua S. Walden (ed.), Representation in Western Music (New York: Cambridge University Press, 2013).

${ }^{23}$ Jim Samson, "Little Stories from the Balkans," in Music and Displacement: Diasporas, Mobilities, and Dislocations in Europe and Beyond, ed. Erik Levi and Florian Scheding (Lanham, MD, Toronto, and Plymouth: Scarecrow Press, 2010), 188.
} 
"typically connotes the artistic, pictorial sense of landscape." 24 This distinction thus encodes the dynamic relationship between abstract space and the subjective experience of that space as outlined by Samson, as well as establishing a framework for understanding how landscape functions simultaneously as both the object and the means of representation.

This article examines just two songs - one from each of the periods proposed by Maggid with a view to understanding both how Rimsky-Korsakov brings elements of landscape into the salon or concert hall, and how, reciprocally, he imaginatively transports the listener back into that environment. Observing the extent to which landscape has been productively employed as a category of reception, the article asks how this notion plays out in Rimsky-Korsakov's songs, whether through his choice of lyrics or through his handling of musical structure. In particular, three approaches are adopted in order to facilitate a more subtle and variegated understanding of his musical "soundscapes" than has been proposed so far. Firstly, landscape is interpreted as a facet of Russian national identity in the second half of the nineteenth century. Second, the evocation of the sounds of the natural world is seen as a metapoetic commentary on the creative act, providing an "internal" commentary on landscape to match the "external" one of the nation. Intertwined with these two themes is a series of parallels between music, literature, and the visual arts, which together form the article's third argument, namely that Rimsky-Korsakov's songs are indicative of a tension between dynamism and stasis that is characteristic of musical representation of landscapes, a quality that has moreover often been seen as characteristic of Russian music generally. ${ }^{25}$

\footnotetext{
${ }^{24}$ Christopher Ely, This Meager Nature: Landscape and National Identity in Imperial Russia (DeKalb: North Illinois University Press, 2002), 9.

${ }^{25}$ Compare Daniel M. Grimley’s claim that “[1]andscape in music....appears to play on a powerful contradiction, between its temporal nature (its perception in time), and the way in which it appears to collapse ordered or linear notions of time into a potentially illimitable sense of space." See Grieg: Music, Landscape and Norwegian Identity (Woodbridge: The Boydell Press, 2006), 58. See too Julian Johnson's observations on the relationship between time and space in "nature music" in Webern and the Transformation of Nature (Cambridge: Cambridge University Press, 1999), 229-36.
} 
Rimsky-Korsakov’s setting of Aleksandr Pushkin’s “Na kholmakh Gruzii” (“On Georgia’s hills"), op. 3, no. 4 (1866), is just one of a very substantial number of oriental songs composed between 1866 and 1882 (ex. 1).

На холмах Грузии лежит ночная мгла;

Шумит Арагва предо мною.

Мне грустно и легко; печаль моя светла;

Печаль моя полна тобою,

Тобой, одной тобой... Унынья моего

Ничто не мучит, не тревожит,

И сердце вновь горит и любит — оттого,

Что не любить оно не может.

(Georgia's hills are covered with the darkness of night;

The Aragva roars before me.

I am sad, yet also calm; my sorrow is radiant;

My sorrow is filled with the thought of you,

Of you, and you alone... Nothing torments

My sadness, or disturbs it,

And my heart burns and loves again - because

It cannot live without loving. $)^{26}$

[Example 1: Rimsky-Korsakov: "Na kholmakh Gruzii" (“On Georgia's hills”), op. 3, no. 4]

\footnotetext{
${ }^{26}$ Translation my own. In Rimsky-Korsakov's version, "lyubit" ("loves") in the penultimate line is replaced with "byotsya" ("beats").
} 
In setting this lyric, Rimsky-Korsakov heightens the images implicitly represented in Pushkin's text. The "nochnaya mgla" ("darkness of night") is depicted in the modal minor tonalities of the song's opening bars, and the sound of the Aragva comes in the form of a bass tremolo. The beating of the poet's heart and the rising sensation of love is suggested by increased motion in the second half of the song, and the poem's Georgian setting leads Rimsky-Korsakov to draw on all of the tropes of orientalist musical cliché (drones, syncopations, melismas, modal harmonies, flattened seconds, and so on). What is suggested in Pushkin's poem is declared in Rimsky-Korsakov's song; the phenomena present in the poet's perception are externalized by musical setting, primarily by means of a piano accompaniment that functions independently of the lyric voice.

Because landscape - whether in poetry, music, or painting - implies both a natural environment subject to depiction and the presence of a viewer, whether implicit or explicit, the representation of landscape generally articulates an active relationship between perceiving subject and perceived object. As Christopher Tilley has suggested, “A centered and meaningful space involves specific sets of linkages between the physical space of the non-humanly created world, somatic states of the body, the mental space of cognition and representation and the space of movement, encounter and interaction between persons and between persons and the human and non-human environment." 27 These relationships are particularly clear in the case of "Na kholmakh Gruzii": the poet is present in the landscape, and his thoughts and feelings are provoked by contemplation of the sublime. At the same time, however, both the poem and the song embody the politics of empire, since the solitary and impressive landscape depicted had been subject to Russian territorial expansion in the first half of the nineteenth century, and the freedom for Romantic poets to imagine fantastic versions of the oriental sublime was bought at the cost of Georgian

\footnotetext{
${ }^{27}$ Christopher Tilley, A Phenomenology of Landscape: Places, Paths and Monuments (Oxford and Providence: Berg, 1994), 10.
} 
independence. ${ }^{28}$ So much is perhaps obvious, yet it is a point worth repeating, since RimskyKorsakov's liberal politics have tended to exempt him from discussions of Russian orientalism. As his memoirs relate, however, he was as susceptible to the tendency to fantasize about the nature of the East as other Russian composers of his day:

Bakhchisaray, with its very long street, stores, coffee houses, merchants' cries, the call of the muezzins from the minarets, the services in the mosques and its oriental music produced the most peculiar impression. Listening to the gypsy musicians of Bakhchisaray, I first became acquainted with oriental music in its natural state, so to speak, and I believe I grasped the main features of its character....In those days the streets of Bakhchisaray, from morning till night, rang with music, of which oriental peoples are so fond; in front of any coffee house there was playing and singing. ${ }^{29}$

Rimsky-Korsakov's impressions are more fantastical than factual: Bakhchisaray is in the Crimea, which, although part of Russia's south in the nineteenth century, was far from being the most “oriental" of its provinces (even though, as capital of the Crimean Khanate until 1783 and a major center of Crimean Tartar culture thereafter, it did enjoy close links with Central Asia). Moreover, Rimsky-Korsakov's perception of the "natural state" of the oriental music he heard there is

\footnotetext{
${ }^{28}$ There is an extensive body of criticism on Russian orientalism in the Caucasus. See in particular Susan Layton,
} Russian Literature and Empire: The Conquest of the Caucasus from Pushkin to Tolstoy (Cambridge and New York: Cambridge University Press, 1994), Harsha Ram, The Imperial Sublime: A Russian Poetics of Empire (Madison: University of Wisconsin Press, 2003), and Stephanie Sandler, Distant Pleasures: Alexander Pushkin and the Writing of Exile (Stanford: Stanford University Press, 1989). See also Richard Taruskin, “'Entoiling the Falconet’: Russian Musical Orientalism in Context," Cambridge Opera Journal 4/3 (1992): 253-80, reprinted in Defining Russia Musically: Historical and Hermeneutical Essays (Princeton and Oxford: Princeton University Press, 2000), 152-85. More generally, see W. J. T. Mitchell (ed.), Landscape and Power, 2nd edn (Chicago and London: University of Chicago Press, 2002).

${ }^{29}$ Rimsky-Korsakov, “Letopis’ moyey muzykal'noy zhizni,” 87-88. 
mediated through existing tropes of orientalist poetry and music, as suggested by the fact that the musicians he hears are actually gypsy performers, and not representatives of any of the "oriental" nationalities within the Russian Empire at all.

As well as situating Rimsky-Korsakov more squarely within discourses of Russian orientalism, an understanding of the relationship between landscape and observer, as well as an emphasis on the evocation of space through musical means, opens up ways of thinking about a further crucial feature of his songs, namely their handling of the relationship between motion and stasis. Pushkin's “Na kholmakh Gruzii” resembles a landscape painting not only because it depicts a scene, but because its depiction isolates that scene from any narrative impulse. Individual images and moods - the darkened hills, the roaring river, the poet's enamored state - are juxtaposed through parataxis rather than being organized into an unfolding narrative through the use of coordinating constructions. Moreover, the poem is not centered on a speaking subject or an autonomous lyric "I." Grammatically, the poet's agency is effaced through the use of indirect constructions; everything happens to him ("The Aragva roars before me," and the original Russian version of "I am sad, yet also calm" is based on a dative construction, literally "to me it is sad and calm"). The subjects that are there work by substitution and synecdoche - it is the poet's sorrow (pechal') and heart (serdtse) that do the lyric's emotional work, and not the poet's perceiving intelligence itself. Still less does nature function as an instance of pathetic fallacy, and there are no instances of comparison ("as," "like," "thus"), which would help to connect the poet to the landscape. Rather, the landscape (the darkened hills, the sound of the river) simply exists, and in its being, it stirs, rather than reflects, emotions in the poet.

Rimsky-Korsakov's response to the formal elements of Pushkin's poem highlights this tension between the static depiction of the natural world and the heightened emotional state of the poet. The first four lines of the poem feature a recurrent series of $\mathrm{C}$ sharp minor pedals, and more broadly, the harmony alternates between the poles of $\mathrm{C}$ sharp minor and $\mathrm{F}$ sharp minor; nature (at least as it is perceived by the poet) is permanent, motionless, and eternal. By contrast, the second 
four lines are set almost as a separate verse; both the vocal line and the accompaniment become more agitated, reflecting Pushkin's increased use of caesura and enjambment, and the penultimate line drives forward as the poet's feelings overwhelm him. Here, the music becomes more goaloriented and dynamic, as if to suggest that the human individual is subject to forces of time, development, and decay, unlike the unchanging environment that surrounds him (as underlined by the return of the $\mathrm{C}$ sharp pedals at the end of the song).

None of this is to argue that Rimsky-Korsakov's "Na kholmakh Gruzii" is in some way a "translation" of Pushkin's poem into musical form, as that would be as limiting and reductive as insisting on representation as the sole feature of realism. In fact, Rimsky-Korsakov's literary sensibility was often tinged with an equally profound responsiveness to the visual, whether in the natural world (primarily), or in painting (less emphatically). Accordingly, his setting of " $\mathrm{Na}$ kholmakh Gruzii" is less a musical equivalent of a pre-existing literary work than an attempt to find self-sufficient musical correlates for both the form of Pushkin's poem and for the visual triggers that motivated it in the first place.

Rimsky-Korsakov was frequently attracted to poems of this kind, and he responded to them by writing music that, like a painting, seems to be frozen in time, at least when the natural world is evoked. Aware that music unfolds in time, and that poems demand to be read according to the logical progression of their layout, but that at the same time the natural world exists beyond the temporal boundaries imposed both by our own human nature and by the dictates of literary and musical form, the composer came up with a series of musical techniques for undoing the perception of temporality in song, and giving instead the impression of a sense of timeless space. He achieves all of this partly through the insistent presence of images of landscapes and the natural world in many of the texts that he sets, but also by his predilection for musical techniques that achieve stasis and give the impression of non-progression. The latter include an inclination to non-functional modal harmonies, the use of pedal points and drones, and the presence of recitative-like vocal lines, often based on recurrent melodic and rhythmic patterns that are not so much developed as simply 
repeated. The natural world provides Rimsky-Korsakov not just with a stock of images that can be represented in musical form, but with an innovative constructive principle governed by the presence of visual rather than temporal images.

It is precisely this musical incorporation of spatial elements that are either represented or implied in poetry that facilitates such a powerful sense of subjectivity in Rimsky-Korsakov's songs. And it is this sense of subjectivity that means his songs are never merely representational, despite their engagement with elements of realist aesthetics. Alongside their evocation of landscapes and the artistic subjectivities that perceive them, his songs also explore how imagery from the natural world can be interpreted metaphorically as a commentary on the creative process. In many of the poems set by Rimsky-Korsakov, the poet contemplates the natural world in isolation. Whether explicitly or implicitly, the presence of a figure in the landscape is an integral part of such songs, just as realist canvases often suggest the perspective of an external viewer beyond the immediate confines of a landscape, not least by their handling of the vanishing point and treatment of the frame. Yet in some of Rimsky-Korsakov's songs, the nature of the poet's perception departs from the quasi-realist mode considered so far, and instead comes closer to a Romantic sense of the natural world as the origin of artistic creativity. A particularly clear example of this strain is Rimsky-Korsakov's setting of Apollon Maykov's "Oktava" ("The Octave"), the third song from his late op. 45 cycle, "Poetu” ("To a poet," 1897-99) (ex. 2).

Гармонии стиха божественные тайны

Не думай разгадать по книгам мудрецов:

У брега сонных вод, один бродя, случайно,

Прислушайся душой к шептанью тростников, Дубравы говору; их звук необычайный Прочувствуй и пойми... В созвучии стихов Невольно с уст твоих размерные октавы 
Польются, звучные, как музыка дубравы.

(Do not think of fathoming the divine secrets

Of poetry's harmony by reading the books of sages:

Instead, wandering aimlessly and alone by the banks of somnolent waters,

Attend with your soul to the whispering of reeds,

And the speech of oaks; feel and grasp

Their unusual sound... In the consonance of verse,

Measured octaves will flow unbidden from your lips,

Sonorous, like the music of the oaks. $)^{30}$

[Example 2: Rimsky-Korsakov: "Oktava" ("The Octave”), op. 45, no. 3]

Maykov's poem dates from 1841, a time when German Romantic thought was a dominant influence on Russian poetry and philosophy. It plays on both the language of nature and the technical vocabulary of poetry to make a link between landscape and artistic inspiration; in Russian, the link is particularly clear, since the word for element - "stikhiya" - is very close to that for a line of verse - "stikh." The "harmony" that the poet enjoins the reader to discern in the natural world here personified through the idea of the "whispering of reeds" and the "speech of oaks" - is reflected in the "consonance" of poetry's form. That the relationship between poetry and the natural world is a musical one is made clear by the poem's title and form: it is an eight-line poem, or an "octave," in which language aspires to the condition of music.

Such a poem seems to demand musical setting, and it is not surprising that it should have attracted Rimsky-Korsakov, who was distinctly sensitive to such supernatural, pantheistic visions of nature. Yet his setting has none of the naturalism that characterized "Na kholmakh Gruzii," or other

\footnotetext{
30 Translation my own.
} 
earlier songs where word-painting seeks to bring out or illustrate the latent meaning of the poetic text. Rather, it is more typical of Rimsky-Korsakov's late method, here described in his memoirs:

I had not composed any songs for a long time. Turning to the poems of Aleksey Tolstoy, I wrote four songs and sensed that I was composing in a different way from before. The melody of the songs, following as it did the twists and turns of the text, began to take on a purely vocal quality, that is, it became such at the very moment of its birth, accompanied by the merest hints of harmony and modulation. The accompaniment was worked out and refined after the composition of the melody, whilst as before, with few exceptions, the melody was created as if instrumentally, that is without reference to the text, and only in harmony with its general sense, or stimulated by a harmonic foundation that sometimes preceded the melody. Feeling that this new way of composing was true vocal music, and being satisfied with my first attempts in this direction, I composed one song after another to words by A. Tolstoy, Maykov, Pushkin, and others. ${ }^{31}$

With its sonorous accompaniment, broad harmonic sweep, and vocal line based on the repetition of key motivic details, this song typifies this late style, in which music does not so much represent the images in a given poetic text as respond to the harmony and wholeness of the natural world. Music does not evoke nature; rather it strives to become nature, or at least akin to it. Likewise, the poet ceases to be an alienated observer of the world, but becomes instead part of its fabric. "Oktava" renounces mimesis, and in doing so, embraces a strain of metapoetic inspiration more typical of the fin de siècle.

"Oktava" illustrates the extent to which Rimsky-Korsakov had moved away from the realist aesthetics that characterized both his earlier songs and the Russian arts of the middle of the nineteenth century more generally. In his songs of the 1890 s, he aligned himself with Russia's

\footnotetext{
${ }^{31}$ Rimsky-Korsakov, “Letopis’ moyey muzykal'noy zhizni,” 206.
} 
neglected Romantic tradition of the 1830s and 1840s, as well as with the nascent Symbolist movement that drew heavily on the Parnassian poetry of precursors such as Maykov. The main transformation in Rimsky-Korsakov's musical life is often held to be his appointment as professor of composition, harmony, and orchestration at the St Petersburg Conservatoire in 1871, upon which he subjected himself to the kind of thorough formal musical training that the composers of the Balakirev circle had so ostentatiously shunned. But this shift from amateur to professional status eventually also produced a shift in aesthetic outlook, in which the realism of the 1860s was gradually supplanted by a form of Romanticism that rooted the source of artistic inspiration in the transcendent mysteries of creation, and sought a justification for art not in social action or realist representation, but in the givenness of the natural order and the place of creativity within that order.

As with "Na kholmakh Gruzii," "Oktava" embeds its metapoetic conceit about the origins of poetry within an evocation of nature's permanence, and hence of the durability of art. To be sure, there is a rigorous formal logic to the poem, which unfolds as an address to the aspiring writer: "Do not think of fathoming the divine secrets of poetry's harmony" - "Instead... attend with your soul to the whispering of reeds, / And the speech of oaks" - "Feel and grasp their unusual sound" - and, consequently, "measured octaves will flow unbidden from your lips." The use of the Russian perfective aspect in these constructions - "ne dumay razgadat'," "prislushaysya," "prochuvstvuy i poymi," "pol'yutsya" - further emphasizes the purposefulness of human endeavor. (Russian verbs exist in one of two aspects, the perfective being used to express successful achievement, whereas the imperfective is associated with process.) Yet this grammatical detail is juxtaposed with the eternal flow of the sounds of nature ("the whispering of reeds," "the speech of oaks"), and it is these implied features of the poem that that are rendered audible in the music, rather than the formal logic of its linguistic structure, particularly through the use of melodic lines that are often symmetrical in form and whose mirror structure suggests the eternal permanence of nature rather than the unfolding narrative structure of human perception. ${ }^{32}$

\footnotetext{
${ }^{32}$ S. D. Maggid, "Stilicheskiye osobennosti romansov N. A. Rimskogo-Korsakova,” 157-58.
} 
In his review of Rimsky-Korsakov's "Noch'," Cui suggested that musical landscapes "have the great advantage over painted ones that a consecutive series of moments can be depicted in them, whereas painting is capable of portraying just one of them." Pleshcheyev's poem is indeed made up of an unfolding sequence of images:

Ночь пролетала над миром,

Сны на людей навевая;

С темно-лазуревой ризы

Сыпались звезды, сверкая.

Старые мощные дубы,

Вечнозеленые ели,

Грустные ивы листвою

Ночи навстречу шумели.

Радостно волны журчали,

Образ ее отражая;

Рожь наклонялась, сильнее

Пахла трава луговая.

Крики кузнечиков резвых

И соловьиные трели,

В хоре хвалебном сливаясь,

В воздухе тихо звенели,

И улыбалася кротко 
Ночь, над землей пролетая,

С темно-лазуревой ризы

Сыпались звезды, сверкая.

(Night flew over the world,

Summoning dreams in people;

Stars rained down, twinkling,

From its dark blue raiment.

Old, mighty oaks,

Eternally green pines,

And melancholy willows

Rustled their leaves to welcome the night.

Joyfully the waves babbled,

Reflecting night's image;

The rye bent low, and the meadow grass

Gave off an ever deeper scent.

The cries of sportive grasshoppers

And the trills of nightingales,

Merging in a chorus of praise,

Quietly rang out in the air,

And night smiled gently,

Flying across the earth, 
Stars rained down, twinkling,

From its dark blue raiment.) $)^{33}$

Rimsky-Korsakov's setting characterizes each individual stanza with varying musical material of a seemingly descriptive character, thereby corroborating Cui's interpretation of the song as a narrative sequence as opposed to a single visual image. Yet Pleshcheyev's final stanza is a near repetition of the first one, and Rimsky-Korsakov's music similarly returns to the material of the opening. The lyric's formal logic is not narrative, developmental, or linear (as in a sonnet, moving relentlessly towards its volta), but cyclical and repetitive. Literature has little choice but to unfold sequentially, although through the use of poetic devices (sound patterning, verbal repetition, syntactic parallelism, stanzaic structure, rhythm, meter, and so on) it can give the impression of a kind of simultaneity that exists outside a strictly consecutive form of temporality. Likewise, music can produce the paradoxical impression of achieving precisely what painting and sculptures do, namely a sense of timeless, eternal being, even as it too unfolds in time. Pleshcheyev's "Noch"” may not be the literary equivalent of a single painting, and it certainly contains as many aural triggers as it does visual images, but in Rimsky-Korsakov's treatment, it begins to resemble something akin to a series of tableaux.

Rimsky-Korsakov's lyrics can, then, be compared to musical landscapes not because they convey features of the natural environment through the quasi-realistic depiction of poetic imagery, but rather because they seek to express the spatial and temporal coordinates of landscape through music's very different structural resources. Writing of the function of landscape in nineteenthcentury music, Carl Dahlhaus offers the following account of its formal means:

\footnotetext{
${ }^{33}$ Translation my own. Rimsky-Korsakov makes a number of small departures from Pleshcheyev's original, omitting "grustnïye ivï" ("melancholy willows") in the second stanza, "rozh' naklonyalas"” ("the rye bent low") in the third, and "kriki kuznechnikov rezvïkh" in the fourth; and replacing "radostno volnï zhurchali" ("joyfully the waves babbled") with "tikhiye vodï zhurchali" ("quiet waters babbled") in the third stanza, and "solov'inïe treli" ("the trills of nightingales") with "solov'inïe pesni" ("the songs of nightingales") in the fourth.
} 
As far as compositional technique is concerned, almost all the outstanding musical renditions of nature...follow a principle that was driven to extremes in modern art music, even serving as the basis for entire works: the sound-sheet, or Klangfläche, outwardly static but inwardly in constant motion. Regardless of whether the scene is a bucolic idyll or a thunderstorm..., the music remains riveted to the spot motivically and harmonically, no matter how gentle or violent its rhythmic motion. To put it another way, a musical depiction of nature is almost always defined negatively, by being excluded from the imperative of organic development which, at least in the mainstream of compositional history, dominated the thematic and motivic structure of nineteenth-century music as well as its harmonic schemes. The Klangfläche conveys a landscape because it is exempted both from the principle of teleological progression and from the rule of material texture which nineteenth-century musical theorists referred to, by no means simply metaphorically, as "thematic-motivic manipulation," taking Beethoven's development sections as their locus classicus. As Hegel would have it put it, musical landscapes arise less from direct tone-painting than from "negative negation" of the character of musical form as process. ${ }^{34}$

“Tone-painting" is, in Dahlhaus's analysis, the least important feature of musical landscape. Instead, its main achievement is the production of an impression of timeless stasis, regardless of any musical motion at a local level. Musical landscape relies on the perception of "the sound-sheet, or Klangfläche," rather than any structural processes.

What is equally significant about Dahlhaus's argument, however, is that it rests on the Beethovenian symphony as a presumed norm; other forms, and indeed other national repertoires,

\footnotetext{
${ }^{34}$ Carl Dahlhaus, Nineteenth-Century Music, trans. J. Bradford Robinson (Berkeley, Los Angeles, and London: University of California Press, 1989), 307.
} 
are to be judged in its light. ${ }^{35}$ Yet this presumption can be resisted by composers who are willing to explore other models of the relationship between form and time. Richard Taruskin and Simon Morrison, for instance, have both discussed Scriabin's attempts at producing symphonic forms that aspire to generate effects of transcendence and otherworldliness that are self-consciously very different from normative models of goal-directed cadential resolution or classical motivic development in the Beethovenian spirit. ${ }^{36}$ Similarly, a fondness on the part of Russian composers for setting a repeated folksong melody against a changing background (famously employed by Glinka in his Kamarinskaya) serves to suggest particular landscapes less through the use of local color than through something closer to Dahlhaus's Klangfläche, static and yet somehow always in motion. ${ }^{37}$ Even Taruskin's analysis of Stravinsky's style in terms of drobnost', nepodvizhnost', and uproshcheniye ("the quality of being a sum of parts," "immobility," and "simplification"), suggests that the Russian national style had its roots in a rejection of Germanic form. ${ }^{38}$ Despite their more modest scale, Rimsky-Korsakov's songs share something of the atemporal musical ambit of much Russian music more generally, and do so, moreover, in spite of their seeming reliance on extramusical literary structures. Mood, atmosphere, and the impressionistic surface (Dahlhaus's Klangfläche) are not secondary, superficial, or incidental details of their musical construction, but

\footnotetext{
${ }^{35}$ As Benedict Taylor notes (citing, inter alia, Dahlhaus), claims about the atemporality of Russian music have often rested on a presumption that it is somehow technically and formally deficient when compared to the supposedly more sophisticated developmental practices of the Austro-German orchestral repertoire. See The Melody of Time: Music and Temporality in the Romantic Era (New York: Oxford University Press, 2016), especially 172-208.

${ }^{36}$ Richard Taruskin, "Scriabin and the Superhuman: A Millennial Essay," in Defining Russia Musically: Historical and Hermeneutical Essays (Princeton: Princeton University Press, 1997), 308-59, and Simon Morrison, "Scriabin and Theurgy," in Russian Opera and the Symbolist Movement (Berkeley, Los Angeles, and London: University of California Press, 2002), 184-241.

${ }^{37}$ Richard Taruskin, "How the Acorn Took Root," in Defining Russia Musically, 113-51.

${ }^{38}$ Richard Taruskin, Stravinsky and the Russian Traditions: A Biography of the Works through Mavra, 2 vols. (Oxford: Oxford University Press), I, 951-65.
} 
are instead central to Rimsky-Korsakov's attempt to convey the subjective impression of the experience of landscape through music. ${ }^{39}$

The uses of landscape in Rimsky-Korsakov's songs are various. Landscape figures as an actual geographical location at a time of Imperialist expansion and constitutes the object of quasirealist representation in musical form; it functions as a commentary on the creative act itself and of an organic relationship between poetry, music, and the natural order; and finally, it engenders the impression of stasis in an art form marked by temporality. Rimsky-Korsakov achieves all of this by incorporating elements of the visual into musical form, whether through his choice of poetic text, or his exploration of compositional strategies that might convey either representational detail or the embodied experience of space itself. Accordingly, his songs provide us with a perhaps unexpected example of how the musical terrain of Russian song was radically expanded in the second half of the nineteenth century, primarily under the influence of other forms of art, whether literature or painting, in which realism was urgently debated. But Rimsky-Korsakov's songs also show us the limits of realism, primarily by illustrating how its claims to objectivity ultimately rest on a series of subjective preconceptions, both ideological (as in the case of Russian Imperialism) and aesthetic (as in the case of metapoesis). There are, moreover, striking parallels with similar developments in the Russian visual arts in the second half of the nineteenth century, as well as with the establishment of geography as a scholarly discipline at around the same time. ${ }^{40}$

Landscape also helps us to distinguish Rimsky-Korsakov's songs from those of his contemporaries, whose approaches both to the handling of text and to the treatment of musical form

\footnotetext{
${ }^{39}$ For a recent attempt to direct the attention of literary scholars towards a similar set of questions, see Hans Ulrich Gumbrecht, Atmosphere, Mood, Stimmung: On a Hidden Potential of Literature, trans. Erik Butler (Stanford: Stanford University Press, 2012).

${ }^{40}$ For a comprehensive exhibition catalogue covering the nineteenth century, see David Jackson and Patty Wageman (eds.), Russian Landscape (Schoten: BAI, 2003). On the rise of geography as an academic discipline, and its treatment of landscape, see Denis J. B. Shaw and Jonathan D. Oldfield, "Landscape Science: A Russian Geographical Tradition," Annals of the Association of American Geographers 97/1 (2007): 111-26.
} 
were very different. For Tchaikovsky, it was the quasi-operatic miniature melodrama, combined with elements of the popular domestic romance, that proved to be the ideal vehicle for his highly expressive musical language. For Borodin, it was a strongly balladic, even epic impulse that facilitate the narrative impact of his songs. For Musorgsky, attention to the rise and fall of speech vividly conveyed the personalities of his lyric subjects. Studies of the Russian song tradition have tended to characterize Rimsky-Korsakov's songs as cold, lacking the emotional spontaneity and directness that are often felt to be characteristic of the genre. ${ }^{41}$ Yet that is to overlook both the sources of their inspiration and the nature of their radical, if unostentatious, inventiveness.

${ }^{41}$ Cui, for instance, refers to the "somewhat cold, descriptive character" of his music (Russkiy romans, 139). 